\begin{tabular}{|l|l|l||}
\hline \multicolumn{2}{|c|}{ PublisherInfo } \\
\hline \hline PublisherName & $:$ & BioMed Central \\
\hline \hline PublisherLocation & $:$ & London \\
\hline \hline PublisherImprintName & $:$ & BioMed Central \\
\hline \hline
\end{tabular}

\title{
Duplicate and die
}

\begin{tabular}{|l|l|l||}
\hline \multicolumn{2}{|c|}{ ArticleInfo } \\
\hline \hline ArticleID & $:$ & 3829 \\
\hline \hline ArticleDOI & $:$ & $10.1186 /$ gb-spotlight-20001113-03 \\
\hline \hline ArticleCitationID & $:$ & spotlight-20001113-03 \\
\hline \hline ArticleSequenceNumber & $:$ & 266 \\
\hline \hline ArticleCategory & $:$ & Research news \\
\hline ArticleFirstPage & $:$ & 1 \\
\hline \hline ArticleLastPage & $:$ & 2 \\
\hline \hline & $:$ & RegistrationDate : 2000-11-13 \\
ArticleHistory & $:$ & OnlineDate \\
\hline \hline ArticleCopyright & $:$ & BioMed Central Ltd2000-11-13 \\
\hline \hline ArticleGrants & $:$ & \\
\hline \hline ArticleContext & $:$ & 130591111 \\
\hline \hline
\end{tabular}




\section{William Wells}

Email: wells@biotext.com

Growing databases of sequence information have allowed Lynch and Conery, in the 10 November Science, to calculate the frequency and fate of gene duplications (Science 2000, 290:1151-1155). Genes are duplicated at a high rate of, on average, 0.01 per gene per million years. The vast majority of these duplicates are silenced within a few million years by deleterious mutations. Polyploidization may result in a greater number of surviving duplicates, as in this case the necessary stoichiometry between gene products is conserved. Selective pressure on the surviving genes increases approximately ten-fold as the duplicates evolve new functions. Although the silenced duplicate genes are no longer functional, they may still be important in speciation. If gene duplication is followed by geographic separation, independent inactivation of one copy of the duplicate in each of the two populations, then mating of the previously separated populations, some of the resulting offspring will be double-nulls. The occurrence of such duplication and inactivation events in multiple genes would result in inviable, multiply null offspring, and thus may constitute a post-mating reproductive barrier encouraging speciation.

\section{References}

1. Science, [http://www.sciencemag.org/]

2. Gen(om)e duplications in the evolution of early vertebrates. 